\title{
Islamic Politics Configuration after New Order: PKB practice in Probolinggo, Indonesia
}

\author{
Zuhri Humaidi $^{*}$ \\ 1 IAIN Kediri, Kota Kediri, Indonesia; e-mail: zuhrihumaidi@iainkediri.ac.id \\ * Correspondence
}

Received: 2019-04-12; Accepted: 2020-09-21; Published: 2020-12-30

\begin{abstract}
After the 1998 reformation era, PKB (Partai Kebangkitan Bangsa - The National Awakening Party) becomes one of the parties that gained a good reputation. Interestingly, unlike NU (Nahdlatul Ulama) in the 1940s to 1970s, when it actively took a part in electoral politics by carrying out the agenda of formalising Islam, PKB sought to synthesise the value of Islam and Indonesia in the context of a pluralistic state and pay attention to secular issues such as political education. In Probolinggo, the issue of political education became one of the post-reform political issues. This paper aims to formulate political education as designed in PKB's political program, as well as the changing of the political Islam articulation after the reformation. To get accurate data and results, a political sociology approach was used to understand political education within the PKB platform, and to measure the extent to which the ideational formulation is capable of being implemented at the practical and local levels in Probolinggo. The data obtained were analysed in three contexts; the context of social and political configuration in Probolinggo, the context of political transformation in NU, and the context of the articulation change of post-reform political Islam. The results concluded that PKB political education in Probolinggo faced several constraints, both structural and non-structural, while the relevance was to provide contextualisation of the reformation at the national level, marking a shift in NU's political paradigm, as well as the transformation of post-New Order political Islam.
\end{abstract}

Keywords: PKB; political education; political Islam; transformation.

Abstrak: Pasca reformasi 1998, PKB (Partai Kebangkitan Bangsa) muncul sebagai salah satu partai yang memperoleh reputasi luas. Yang menarik, berbeda dengan NU (Nahdlatul Ulama) tahun 1940an s/d 1970-an, ketika aktif berkiprah dalam politik elektoral dengan mengusung agenda formalisasi Islam dalam kehidupan kenegaraan, PKB berupaya mensintesiskan unsur keislaman dan keindonesiaan dalam konteks kenegaraan yang plural serta memberi perhatian terhadap isu-isu sekuler seperti pendidikan politik. Di Probolinggo, isu tentang pendidikan politik menjadi salah satu isu politik pasca reformasi. Paper ini bertujuan untuk merumuskan pendidikan politik sebagaimana dirancang dalam program politik PKB, serta konteks perubahan artikulasi Islam politik pasca reformasi. Untuk mendapatkan data dan hasil yang akurat, penulis menggunakan pendekatan sosiologi politik yang bertujuan untuk memahami pendidikan politik di dalam platform PKB, dan berikutnya mengukur sejauhmanakah rumusan ideasional tersebut mampu dimplementasikan pada tataran praktis dan lokal di Probolinggo. Data-data yang diperoleh kemudian dianalisis dalam tiga konteks, yaitu konteks konfigurasi sosial dan politik di Probolinggo, konteks transformasi politik di $\mathrm{NU}$, serta konteks perubahan artikulasi Islam politik pasca reformasi. Hasil penelitian menyimpulkan bahwa pendidikan politik PKB di Probolinggo dihadapkan pada sejumlah kendala pokok, baik sruktural maupun non-struktural, Sedangkan relevansinya adalah memberikan kontekstualisasi terhadap reformasi yang berlangsung di tingkat nasional, menandai pergeseran paradigma politik $\mathrm{NU}$, serta transformasi Islam politik pasca Orde Baru.

Kata Kunci: Islam politik; pendidikan politik; PKB; transformasi. 


\section{Introduction}

PKB (Partai Kebangkitan Bangsa - The National Awakening Party) is one of the post-reform Islamic parties, which for some time received wide attention. This was caused by two important aspects; the acquisition of significant votes in the 1999, 2004, 2009, and 2014 elections, ${ }^{1}$ furthermore, PKB emerges from the largest Muslim organization in Indonesia, NU - Nahdlatul Ulama (Kusmayadi, Agung, \& Andrias, 2016). In the Probolinggo district, PKB is the strongest party. This area is an enclave of PKB that has won and gained a significant vote in 4 times the election (Ghozy, 2019). ${ }^{2}$ The success of PKB cannot be separated from the social and religious structure of the Probolinggo community, which incidentally is a devout follower of NU. Although it was different from NU in the 1940s to 1970s, when it was involved in electoral politics which carried the agenda of the return of the Jakarta Charter, the application of Islamic Sharia in the state, and the struggle of Islam as the basis of state philosophy, PKB sought to synthesise Islamic value and Indonesian-ness in a pluralistic state context and paying attention to secular issues such as political education (Assyaukanie, 2011). The PKB political paradigm which included Pancasila as the party's principle and its neglect of the formalisation agenda of Islam which was the main issue of political Islam (Keddie, 1986) ${ }^{3}$ since the struggle for independence would only be understood in the context of the transformation within NU and the political Islamic movement in general.

The issue of NU's political transformation and, more generally, the configuration of post-reform political Islam gained serious attention from many scholars, including Fealy, Bruinessen, Feillard, Amir, Noorhaidi, and Hilmy. Fealy observed NU's political journey in 1952-1967, the period in which NU actively took part in the practical political arena. According to Fealy, NU politics is based on a Sunni ideology that places the highest priority on the protection of Islam and its followers, thus encouraging militancy and accommodation. Fealy rejected some of the Indonesianists thesis, such as Daniel Lev and Arnold Brackman, about NU's political opportunism. The 1952s-1967s period demonstrated the balancing role of NU from Masyumi's radical and rigid attitude on the one hand, and on the other hand, NU's accommodation and militancy as part of Nasakom Soekarno's elements. NU maintained the ideological consistency in Soeharto and post-New Order regimes ended (Fealy, 2003). This also become the concerns of Bruinessen and Feillard, they highlighted the strategy adopted by NU in the form of strengthening civil society, especially based on nahdliyyin, explain the movement orientation chosen after the 1998 reform, as well as a party that has strong associations with NU (Bruinessen, 1999; Feillard, 1999).

While Amir (Amir, 2003), Noorhaidi (Hasan, 2006), and Hilmy (Hilmy, 2015) highlighted the repositioning played by the power of political Islam after the New Order, as well as the contestation that took place. Radical movements, whether closed (clandestine) like Jama'ah Islamiyah, or open ones such as Laskar Jihad, FPI, MMI, Laskar Jundullah, and HTI appear in a new more militant performance.

${ }^{1}$ In 1999 elections, PKB was in third place with 13,321,837 votes or $12.62 \%$ of the votes, with 51 seats. Meanwhile, PDI-P ranks first with 35,621,436 votes or 33.75\%, with 153 seats, and second place is Golkar with $23,675,511$ votes or $22.43 \%$ with 120 seats. In 2004 election, PKB again ranks third with 11,989,564 votes or $10.57 \%$ with 52 seats, Golkar Party ranks first with $24,480,757$ votes or $21.58 \%$ with 127 seats and second place is PDI-P with 21,026,629 votes or 18.53\% with 109 seats. In 2009 election, PKB was in seventh place with 5,146,302 votes or $4.95 \%$ with 28 seats, while the Democrat Party came in first with 21,655,295 votes or $20.81 \%$ with 148 seats, and the second placion, PKB was in fifth place with 11,292,151 votes or $9.04 \%$ with 47 seats, while the first place was PDIP with 23,673,018 votes or $18.96 \%$ with 109 seats, and second place was Golkar Party with 18,424. 715 votes or $14.75 \%$ with 91 seats.

${ }^{2}$ For example, in Probolinggo, in 2004, 2009 and 2014 elections, PKB was in the top rank. In 2004 elections, PKB received 215,201 votes or $33.57 \%$ with 15 seats out of a total of 45 contested seats. In 2009 election, PKB received 88,904 votes or $17.12 \%$ with 9 seats out of a total of 50 contested seats. In 2014 election, PKB received 171,923 votes or $26.44 \%$ with 14 seats out of a total of 45 contested seats.

${ }^{3}$ In Islamic studies, as expressed by Nikki Keddie, the term political Islam is also called "Islamist", which is a movement designed to increase the role of Islam in society and politics, usually by aspiring an Islamic state. While the term "Islamic" refers to the life of faith and diversity in Islam (Keddie, 1986). 
Whereas the old political Islam, based on a traditionalist and modernist Islam which was once dominant in the Old and New Order eras, chose a more moderate path. This is in line with Asef Bayat's thesis on the phenomenon of Post-Islamism, which is a tendency of the Islamic movement to be willing to follow democratic procedures with a more pragmatic and realistic program, ignoring purely rigid ideological schemes (Bayat, 2002). The results of research conducted by Amir on the five largest massbased Islamic parties; PKB, PAN, PPP, PKS, and PBR, showed a paradigmatic shift that was different from the previous generation party (Amir, 2003). Even though some of them, PKS, PPP, and PBR still included the formal principle of Islam as the basis of the party, yet the direction of the party stayed on the new paradigm. In the party's goal, none of them formulated the ideals of establishing an Islamic state or the re-inclusion of the Jakarta Charter. For the latter problem, after the 1999 General Election, there was indeed a small debate about the Jakarta Charter, but it quickly disappeared and replaced by other issues. They prefer pragmatic and inclusive political steps by entering into the available political system to gain great access to the decision-making process without abandoning Islamic principles (Kersten, 2018).

This paper focuses on efforts to obtain the model and implementation of PKB political education in Probolinggo from 1998 to 2014. As a political experiment, this is interesting to study, not to measure the success or failure of the target of the program, unless to see the practical implementation of the Post-Islamism phenomenon as mentioned by Asef Bayat. The description is examined in three levels of analysis; 1) in the context of PKB's social and political configuration in Probolinggo; 2) in the context of NU's political transformation; 3) as a form of the articulation development of political Islam in Indonesia. The three-dimensional approach is a three-stage analysis proposed by John O. Voll in studying a political phenomenon, especially Islamic politics so that the problem can be described in a more comprehensive and fundamental (Voll, 1997).

In finding the data, PKB documents and archives at the national level were used. As for data gained from Probolinggo, the author used to interview and observation.

\section{Islamic Political Party in Indonesia: A Theoretical Framework}

Islamic political parties, framework, and criteria vary according to the adopted perspective. Understanding it is sometimes difficult since the reformation began, Indonesian Islamic parties appeared in a non-monolithic form. Some of them still use Islamic symbols such as names, principles, image signs, organizational structures, and others. The others tend to leave the symbols of Islam, but the mass base, organizational patterns, and leadership have a very close relationship with Islam. Accordingly, in this paper, the definition of an Islamic political party is broadly understood for the following criteria:

First, the use of Islam as a basic principle of organization. Second, symbols that are identical to Islam, such as names, organizational structures, images, and so on. Third, the main social basis supports the existence of the party in the Muslim community or certain groups such as NU or Muhammadiyah. Fourth, the organizational structure is influenced by Islamic teachings, such as the use of terms that are closely related to it such as the Majelis Shura, Majelis Tanfidz, Muktamar, Mabda' Siyasi, Majelis Syari'ah, Shari'ah Council, and so forth. Fifth, the party is led by figures who have been for a long time struggling with Islamic organizations. Sixth, the political policies are often oriented towards the interests of the Muslim community in particular, as well as the wider community. Thus, PKB, although it does not use Islamic symbols and principles obviously, can be classified as an Islamic party. PKB, from the very beginning, indeed declared itself as an open party determined to promote plurality, however, if it is examined through the criteria mentioned above, PKB has a clear Islamic identity.

Regarding political education, Gabriel Almond explained that one of the functions of the party is the function of socialisation and political education. Almond mentioned that socialisation is a process of teaching community values, which are political values and culture. In Almond's view, there are two interesting important things in this process; first, political culture, and second, political socialisation.

Political culture includes the values, attitudes, and responses of citizens to political life and government. Political culture varies according to the level of community development, yet at least three 
variations can be identified; first, participant political culture, a society that engages in political activities, at least in voting, and obtaining considerable information about political issues. Second, subject political culture, a passive society who abide the government officials and the law, but does not involve themselves in politics. Third, parochial political culture, a society that is completely unaware or ignores the existence of government and politics. They could be illiterate, apathetic, or live in a remote area (Almond, 1997).

As for political socialisation illustrated by Almond, it is an inheritance process and at the same time the formation of political values and behavior, hence it plays a role in changing the parochial political culture in a more participatory direction. Political socialisation runs both through informal patterns, namely the formation of values throughout one's life from social interactions and experiences, as well as through formal patterns, namely transmission and teaching programs carried out by governments, educational institutions, and political parties.

Political education in James S. Coleman's description is not different from political socialisation. The use of the term political socialisation is due to the negative connotation of the label of education. According to Coleman, political education is a process in which individuals obtain attitudes/feelings towards the political system and their role in it which includes; cognition (what is believed about the political system, its existence, and mode of operation), feeling (how someone feels about the political system), and sense of political competence (the role of the individual in the political system) (Coleman, 1965).

Thus, both Almond and Coleman emphasise that political education has two important elements, namely the socialisation and strengthening of certain values in the political culture of society and efforts to increase the values, attitudes, and responses of citizens to political and governance mechanisms.

\section{Political Islam and PKB Political Experiments}

Post-New Order politics brought several important changes including the restructuring of the state system and national politics (Liddle, 1972). Political sectors outside the country are allowed to develop. People from diverse groups are free to establish political parties, including the establishment of Islamic parties (Dhakidae, 1999; Evans, 2003).

Looking at the dynamics of the political parties' development, it can be concluded that there is an important shift in Indonesia is a fact, the shift from the state to political society, from bureaucrats to politicians. The state is no longer the main and only actor who determines Indonesia's political formulation in the future. Non-state forces, Civil Society and Political Society gain a reputation and trust to make fundamental changes for the realisation of an open and democratic society (Lay, 2006). Another dramatic change is the emergence of Political Islam as the main force that has drawn attention after so long on the margins of state power. Marginalised political Islam has now found its legal space to become a major political actor (Wahyuddin, 2016).

From this context, the emergence of PKB on the national political stage marked two shifts; the strengthening of non-state actors and the rise of the aura of political Islam. PKB was born from the largest religious organization in Indonesia, NU. In the last few decades of the Soeharto regime, NU withdrew from the practical political arena by focusing its movement on the social sphere of society (Feillard, 1999). However, the post-Soeharto political situation encouraged nahdliyyin to provide maximum political participation from NU, at least four political parties were born; PKB, PNU, PKU, and SUNI. Among the four parties, PKB has a more strategic position because it was officially released by PBNU, and it became the most representative of NU's return to politics.

From 1999-2001, due to Abdurrahman Wahid's election as RI president, PKB positioned itself as the main political pillar of Abdurrahman Wahid's presidency. There did not appear to be significant efforts to implement the vision in the party program. It was only since 2002 that the party's orientation began to be directed at improving neglected political resources, including by forming relevant new institutions, encouraging regional councils to pay attention to the quality of constituents, or by raising issues as the Advocacy Party (Edy, 2006; Hermawan, 2004). This step was supposed to be done because the functions of parties are socialisation and increasing public awareness. This function becomes 
increasingly apparent and is needed when the political climate is more open (Weiner \& La Palombara, 1981). The openness that feeds Indonesia's political climate causes an explosion of participation that has led to political violence, especially at the grassroots level. This phenomenon arises because the separation of society from political life brings the consequence of an inadequate understanding of political pluralism and the lack of social institutions that can manage it. On the other hand, in the 2004, 2009, and 2014 elections, the number of abstentions was increasing due to a decrease in the level of public trust in the party. Apathy towards the party was caused by the emergence of community disappointment in the party's performance since the reformation (Salim HS \& Fauzan, 1999).

\section{Political Education in Discourse and Practice}

From the theoretical basis mentioned earlier, political education has two important elements, namely; the socialisation and strengthening of certain values in the political culture of society as well as efforts to increase the values, attitudes, and responses of citizens to political and governance mechanisms (Almond, 1997). The two elements of political education have been clearly illustrated in the vision, platform, and rules of association (AD/ART) of PKB. In Article 5 of PKB rules, a party function is clearly defined; "As a place for every Indonesian citizen without distinguishing between origin, ancestry, ethnicity, class, religion, and profession. As a place to improve education, civil rights, and political participation." (Tim DPP PKB, 2002a)

Furthermore, in its political recommendations decided in April 2001, the Syura Council emphasised the strategic steps that must be taken by the party, including the political empowerment of the people. In the explanation, it is explained that a large state of Indonesia must be supported by an empowered society namely the Indonesian Civil Society. People who are empowered both politically and economically will prevent excessive power penetration and on the other hand can help government tasks, even carrying out the difficult tasks of the state. The synergy between democratic government and empowered society will create a just, prosperous, and democratic national life (Tim DPP PKB, 2002b).

Whereas in Mabda' Siyasi of PKB which consists of nine basis points, it is clearly outlined about political education as Gabriel Almond's category. On the sixth point of Mabda' Siyasiy, explained that:

...Power manifestation must be used to extend the empowerment of the people to solve their problems more beneficially. The National Awakening Party (PKB) has committed that the power which is essentially a mandate must be accountable before God and can be controlled by the people management. Control over power is only possible when the power is not infinity and not concentrated in one hand, and is in an institutionalist system mechanism, not resting on individualistic power. Space must always be opened for power competition and the balance of power as an arena for ideas to improve the quality of the nation in the real sense. The understanding does not only apply in viewing power in the state but must also be reflected in the internal party. (Tim DPP PKB, 1998)

This confirms the commitment of PKB to increase the ability and political awareness of citizens because only then can the balance of power and control of the state be carried out. Raising awareness about nationality and democracy will determine the quality of responses to political and governance mechanisms. Political awareness and ability are understood at two levels; at the level of increased response to political mechanisms and state that occurs so that "the power that is essentially a mandate must be accountable before God and can be controlled by the people management" (Tim DPP PKB, 1998). This was realised through the socialisation of General Election and Local Election, political empowerment in party's domain such as in the labor, farmers, fishermen, etc, transparency in political and government processes, and discourse on improving public facilities in the media and so forth. Whereas at the second level, it is the strengthening of certain values such as democracy, anti-violence politics, Pancasila, and moderate Islamic values. In another part of Mabda' Siyasi, it is explained the idealisation of the state and society aspired by the party includes national, Islam, and democratisation values. These three values inspirit the entire article in Mabda' Siyasi. Pancasila and the ideals of the 
independence proclamation became the foundation of all party programs based on the reality of social plurality and commitment to the Republic of Indonesia. While the Islamic value is clearly illustrated, not merely in the vocabulary contained such as al-shidqu (honesty), al'adalah (justice), al-musawa (equality), and so forth, but the strength of Islamic values itself. One of them was well recorded in the party's idealisation of society. The ideal society aspired must fulfill five basic principles (usul alkhamsah), namely; (1). Guarantee for life safety and right (hifdzu al-nafs), (2). Religious freedom and guarantee to carry out beliefs (hifdzu al-din), (3). The maintenance of reason and freedom of expression (hifdzu al-aql), (4). Protection for the continuation of the next generation (hifdzu al-nasl), and (5). Property maintenance (hifdzu al-mal).

Therefore, drawn from Mabda' Siyasi and the Rules of Association, four values underline PKB objectives, they are (a) realising the hope of independence of the Republic of Indonesia as outlined in Pancasila and 1945 Constitution; (b) realising religious values (read; Islam) that spread mercy, peace and benefit to the universe; (c) creating a just and prosperous society physically, materially and spiritually, (d) realising a democratic nation, open, clean and noble. Even though the vision and the objectives are ideal conceptions that still need to be assessed at a practical level and may be found in other parties, the party's vision and foundation are ideological values and program accentuations that PKB wishes to achieve. Thus, it is illustrated that PKB fight the ideological values is not on formal Islamic teachings, but on the substantive values which are found through the media of political education (Litbang Kompas, 2004).

At the program level, in response to issues develop in the community, PKB focuses on emphasising the importance of education, strengthening values, and increasing resources. The program covers political, economic, legal, social, religious, defense, economic, and women's empowerment issues. In realising the seven main programs, seriousness, patience, and a unified effort based entirely on the principles of democracy and justice are required. Accordingly, as a political party, its political program explained that:

The National Awakening Party (PKB) develops a competitive, honest, healthy, and ethicalpolitical culture implemented into political behavior, to develop the dynamics of democracy in society and the country. Democratic political culture must be developed through education and people participation as part of the social control in the country (Amir, 2003).

The phenomenon indicates that PKB, as an Islamic party, is more likely to interpret Islam in the context of nationalism and democracy. These three things are intertwined in an unseparated symbiosis. Such formulation can be observed from the views of PKB elites as well as the developing spectrum of thought in it. This spectrum determines the basis and direction of the party. Gus Dur's ideas and role in this context are important to be elaborated. Gus Dur was the main figure in the NU reform of thought since the 1980s and the founding father of the PKB establishment. According to Gus Dur, Islam does not need to be expressed in the form of formal institutions but more importantly, the value of Islam must be strongly reflected in it. In the party context, it is not important whether a party adheres to the Islamic principle or not, but is more determined by the party's ability to internalise Islamic values. Therefore, Gus Dur and other PKB founders made Islamic values the main instrument in the founding of the party, on the other side, they refused if PKB were categorised as secular parties only because they did not use Islamic symbols.

Nevertheless, one thing that should be more seriously formulated by PKB is how to formulate the platform and the discourse into a structured and broad-based real program. Such formulation is very important because PKB's choice to leave the Islamic symbol and direct it to broader issues such as political education is an important paradigmatic shift in the course of Islamic parties. In Probolinggo, the models of political education carried out are quite a political experiment, and far from the ideal formulation as formulated in the party platform. The formulation in the form of action is faced with several fundamental problems such as weak party infrastructure, lack of resources, party oligarchies, internal conflicts, and so on so that political education effectively moves at the discourse level but is not at the implementation. 


\section{Political Education Model in Probolinggo}

From the research conducted in several locations in Probolinggo, programs, and actions classified as PKB political education are varied. Some of them can be mapped as follows:

\section{Election Campaign}

In Probolinggo, PKB used the momentum of reformation to introduce itself and mobilise the community to the lowest level, neighborhood association (Rukun Tetangga - RT). It got easier because the establishment of PKB in Probolinggo directly involved, both formally and informally, PCNU (Pengurus Cabang Nahdlatul Ulama - NU Branch manager) Kraksaan and PCNU Probolinggo so that it had the ease of building party infrastructure. Even though since the resignation of Gus Dur from the presidency, there has been a strict separation between the management of NU and PKB.

The campaign is one means of mobilisation. In 1999 and 2004 campaigns, PKB emphasised the existence of Pancasila and NKRI (Negara Kesatuan Republik Indonesia - the unitary State of Indonesian Republic). The campaigners stated that PKB remains under Pancasila and the NKRI because NU figures were also involved in establishing the country. Gus Dur was an important icon for the campaign and one example of how religious struggle, political struggle, and national struggle united. "Hubbul Wathan min al-Iman" (loving the motherland is part of faith) is the popular slogan of the campaign. Such mass campaigns become an important medium for PKB for mobilisation and socialisation. Mobilisation and socialisation are not only in the sense of show of force which is indeed important for a party but to instill certain values that the party stands for (Muhammad Alfayumi, personal communication, June 19, 2018).

In the 2009 elections, PKB in Probolinggo faced serious fragmentation. Mass campaigns remain an effective tool. For Kiai Hawasik Mannan, PKB campaigns have become increasingly specific. PKB does not only reject all efforts to replace NKRI but also rejects the radical Islamic movement. According to Mannan:

After the reformation, new Islamic movements emerged in Probolinggo, such as LDII (Indonesian Islamic Propagation Institute), FPI (Front Pembela Islam - Indonesian Defender Front), HizbutTahrir, and so forth. They were militant spreading their teachings, door to door, mosques, and musolla. As a party, PKB opposes such radical views because PKB is nahdliyyin. If Islam in Probolinggo becomes radical like LDII, FPI, Hizbut-Tahrir, and Jama'ahh Tabligh. PKB is very disadvantaged" (Hawasik Mannan, personal communication, June 20, 2018).

Culturally, PKB teachings developed are indeed different from the Islamic teaching embraced by the majority of Probolinggo people. In the world of parties, PKB positioned itself differently from other Islamic parties such as PKS and PPP (Partai Persatuan Pembangunan - United Development Party) which demonstratively used Islamic symbols. It can be seen in the 2004 campaign when Pancasila, nationality, and Islam rahmatan lil alamin became quite a dominant theme.

Other forms of the campaign appear in the form of banners, leaflets, pamphlets, and stickers and fill the public space in Probolinggo. According to Kiai Hawasik Mannan, the issues of the leaflets included the eradication of corruption, greening, religious harmony, Islam rahmatan lil alamin, Probolinggo prosperous, and justice mission as well as various other issues following PKB platform. It is not only media to attract public attention, but also as a form of values socialisation. Kiai Hawasik exemplified the veil problem as one of how party values are socialised in real lives. PPP and PKS in Probolinggo emphasised the veiled obligation in their campaign, in contrast, PKB did not address the issue and let the community choose their respective religious views.

\section{Training of Political Cadre}

In this case, according to Kiai Husein Asy'arie, PKB conducted cadre training twice, namely political management training for party administrators held in May 2006 in Probolinggo and leadership training for the young generation in Zainul Anwar Islamic Boarding School in January 2007 (Kiai Husein Asy'arie, personal communication, July 23, 2018). The first training consisted of political 
management for Branch Managers and PAC representatives. The activity is an attempt to provide insight and professional political standards due to the weak ability to organise and manage conflict among PKB residents. The training lasted three days with professional trainers from Surabaya. According to Asy'arie, PKB has the most extensive support in Probolinggo, yet is weak in party management and resource management. With this training, at least the management has basic knowledge and skills in politics to facilitate the realisation of a modern and open party. Furthermore, besides basic knowledge of political management, the materials also concern the values adhered to by PKB, Islam rahmatan lil'alamin, and the importance of respecting plurality. In this case, Gus Dur was the main figure in PKB and NU who were holding the idea. These values must be shared with PKB administrators, and incidentally, in Probolinggo, there lives a minority group such as the Chinese community. As a big party, PKB must have a contribution in bringing about peace and tranquility, in fact, there has never been a massive ethnic conflict and religious sentiments such as in Situbondo.

The second training was a collaboration between PKB and PMII (Pergerekan Mahasiswa Islam Indonesia - Indonesian Muslim Student Movement) Probolinggo with the young generation as trainees. Participants are not limited to PKB cadres, but the younger generation broadly. However, it is predictable that these young generations are generally NU young generation affiliated with various organizations, such as PMII, IPNU-IPPNU (Ikatan Pelajar/Putri NU - NU Male and female student association), Youth Organization, Pesantren envoys, BEM (Badan Eksekutif Mahasiswa - Student Executive Board), and so on.

In addition to the mentioned training, regeneration also takes place in a more informal form. At the home of PKB Secretary-General, Ahmad Badawi, every early month from the beginning of 2016 until the time when this research took place, there was an open discussion attended by various elements (Ahmad Badawi, personal communication, July 14, 2018). In general, those present were the younger generation and figures in Probolinggo who discussed various issues around politics, nationality, and Islam.

\section{Formation of Farmers and Fishermen Organizations}

The formation of farmer and fishermen organizations is sporadic. Found in this research, the farmer organization formed by PKB is in Besuk District and other mentions in Wonoasih District. For the latter, the writer has not gotten the data directly. The agricultural organization formed in Besuk District started from the scarcity of fertilisers in this area. This situation caused the chairperson of PAC (Pimpinan Anak Cabang - the head of sub-branch of NU) Besuk, who is also a farmer, to form a small organization for farmers around 2008 (Soetrisno, personal communication, July 11, 2018; Haji Muhdor, personal communication, July 07,2018$)$ ). This organization was originally intended for farmers could easily obtain fertiliser and sell tobacco leaf harvests to warehouses.

Soetrisno admitted that as a party program, this step could not be separated from political interests. There was a party ideology and mass mobilisation carried out by PKB management towards members and farmers outside the organization. Incidentally, after it was formed, the 2009 elections took a moment, so that the organization was involved with political activities.

Regarding the fishermen's organization, Soetrisno said that PKB also initiated a fishing organization in the Paiton sub-district, in Sidodadi village. The village is located on the north coast and is one of the biggest fish producers in Probolinggo. He believed that PKB constituents in the coastal area needed to be maintained and expanded because PDIP (Partai Demokrat Indonesia Perjuangan Indonesian Democratic Party of Struggle) has also a strong influence in the area. Moreover, this is necessary to prepare for the upcoming 2009 elections. By multiplying the organization, PKB will be easier to carry out party ideology, maintain constituents, and expand the mass base.

\section{Greening environment program}

Greening the environment is an important issue not only for PKB but also one of the main issues in the 21st century. PKB formulates programs for the issue, although it has not been carried out systematically. From interviews with residents in Binor village in the Paiton sub-district, it was found 
that PKB was involved in a reforestation action in the coastal area conducted in 2015 (Ja'far Sodiq, personal communication, July 16, 2018). The action is full of party political interests.

According to Zaidi;

Since the construction of PLTU in the 1980s, Binor changed a lot. People changing correlated with nature changing. The weather became hot, rising seawater, and scattered coal powder resulted in the emergence of coughs and lung disease. The company has an AMDAL(Analisis Manajemen Dampak Lingkungan - environmental impact assessment) obligation. PKB and NU took the opportunity to formulate programs that were beneficial for Binor residents (Zaidi, personal communication, June 30, 2018).

It is not clear whether the initiative came from $\mathrm{NU}$ or $\mathrm{PKB}$, but then the company agreed to have a dialogue with residents facilitated by NU and PKB. Complaints arise not only on environmental issues but on company guarantees to give priority to the work of Binor villagers.

Based on the regulation, the company had an obligation to help residents. However, without the involvement of NU and PKB as a mediator and facilitator, it would be difficult to implement because of the lack of people's knowledge.

\section{Kiai Patronage and Religious Activities}

Following the Clifford Geertz concept, in the context of traditional societies like Probolinggo, Kiai, as a cultural broker, connects people with the world. Although this function is gradually transformed because technology, education, and media advancement encourage people's independence in accessing information, in certain areas the mediocre function is still strongly needed.

As the party with the strongest Kiai support in Probolinggo, PKB has a large cultural resource. The role of the Kiai does not take place at the formal level such as being a party official or as a campaigner in the general election, but they take place at a more informal level. For example, in the 2001 case of Gus Dur detonation, PKB and nahdliyyin residents' disappointment did not escalate into radical resistance. It was because of the role Kiai in reducing the tougher conflict.

Kiai's position is well understood by PKB elites that they regularly visit them, not only to ensure support but to explain the values, direction, and programs of PKB. Kiai is expected to be able to translate it well into society, something that PKB elite cannot do. Like Kiai Abdul Haq who has been the Chairperson of the PKB Shura Council from 2001 to 2006. He not only became a caregiver for Nurul Jadid Islamic Boarding School but also had broad access to all levels of society. He regularly fills religious sermons, wedding rituals, slametan and opens his house to all citizens. On various informal occasions, he tells about political phenomena that occur and the importance of maintaining PKB as a political organ of Nahdliyin. To some extent, he also instilled an understanding of the direction and ideals of PKB in the broader national context. The role of Kiai Abdul Haq is only a copy of the work of other Kiai. Thus, it is clear that the role of the Kiai in Probolinggo is not limited to being a vote-getter, but rather as an effective mediator (Muhammad Zubaidi, personal communication, July 13, 2018).

\section{Empowerment of the Mosque}

From 2005 to 2018, when this research was conducted, several mosques in Probolinggo were worried by the emergence of new congregations that were identified as Tabligh and Salafi congregations. The emergence of the new congregation was suspected of having a mission to seize and change religious practices believed by the local community, as happened in the Raudlatul Jannah mosque, Besuk Agung village, Besuk sub-district (Ustad Abu Bakar, personal communication, July 27, 2018). For Kiai Anwar Khoiri, the phenomenon was not solely due to the expansion of the Islamic Fundamentalist which had been carried out in the past few years, but more because of weaknesses in mosque management among NU residents (Helfi, personal communication, July 27, 2018). It must be admitted that there has been a big agenda among fundamentalist Muslims, such as PKS, Hizbut-Tahrir, LDII, and so on, to seize nahdliyyin citizen base mosque. The mosque becomes an entry point for the 
spread of the ideology they profess. However, Kiai Anwar mentioned that the problem is merely poor mosque management.

This then became the main attention not only by NU management but also by PKB. PKB management in Besuk realised that if nahdliyyin residents converted to Fundamentalist Islam, that would be the same as the disappearance of PKB's main constituent in Probolinggo. Therefore, PKB Branch management recommends all PAC management and branch management to pay attention to the existence of mosques in their respective environments. Therefore, even though Kiai did not carry the party's name because of the risk, Kiai together with mosque takmir (mosque supervisor) and community leaders in Besuk re-established takmir organization and the youth organization of the mosque.

Those six things are a model of political education carried out by PKB in Probolinggo. The six models, intentionally or unintentionally, seem to have described the process of political education that took place. Although it takes place sporadically and is highly dependent on the involvement of creative actors, the six models and the political processes are important to be further analysed in term of weaknesses and strengths, and how important their role is in determining the dynamics and political format in Probolinggo, and in the Indonesian context.

\section{PKB Political Education in Three Analysis Contexts}

\section{Context of political and Social configuration in Probolinggo}

As described earlier, PKB's practical activities that can be identified as political education consists of six models; the election campaign, cadre political training, the formation of farmer and fishermen organizations, environment issues, patronage of clerics, and religious activities, and mosque empowerment. The six models require further analysis and must be noted separately about their strengths and weaknesses and the possibility of development in the future. In the research, the researcher was in the location for approximately 3.5 months searching for the required documents and conducting in-depth interviews with informants from PKB management, NU, residents and community leaders, government bureaucracy, and so on. However, only a few documents were obtained from Probolinggo DPC (Dewan Pimpinan Cabang - branch council) PKB that are related to this study. Most documents were obtained from PKB at the National level and DPW (Dewan Pimpinan Wilayah - regional council) of East Java. The document obtained at DPC (branch council) level cannot properly describe the party's programs and activities, so for this research, the databases mainly on the results of interviews with several informants.

From the findings, it can be concluded that PKB Probolinggo's political education which is a manifestation of the PKB platform which was then recorded in six models is confronted with some obstacles. These weaknesses can be classified as follows; first, there is no professional documentation, analysis, and management of party activities. As a result, many programs run sporadically, temporarily, and tend to be inefficient. Second, the lack of professional cadres in PKB so that the party has difficulty in institutionalising various political education programs that have strategic meaning. Such professionals could mean the lack of mature PKB cadres in politics or like Herbeth Feith's thesis to functioning more like a mass mobilizer than an administrator (Bruinessen, 1999). It could also mean a lack of cadres from certain professions, such as lawyers, doctors, judges, engineers, and so on. Difficulties in institutionalising are also caused by conflicts that continue to engulf internal parties. Third, dependence on actors is not sufficiently successful in building party infrastructure. Fourth, PKB cadres tend not to pay attention to the importance of building coalitions with several strategic groups such as the Chinese community, which economically and politically play an important role. Fifth, the emergence of a tendency, which Robert Michels calls an oligarchy, raises programs solely for the shortterm interests, without regard to the constituents' aspirations and needs, party ideological values, and so on. Oligarchy starts from the tendency of Neo-conservatism, which is not only in the sense of ignoring the values that were defended during the reformation but merely a backlash to defend the party for the sake of the party itself. 
Those are obstacles faced by PKB Probolinggo in implementing political education programs for constituents and the larger community. That does not mean that the political education carried out during the founding of PKB in 1999 until 2018, when this research was conducted, lost its relevance to the social and political dynamics in Probolinggo. The political program, without denying previous notes, is one of the significant factors that influence the changes. The 1998 reform was a great political momentum that would not be meaningful without the presence of awareness and political participation from the community. In the context of Probolinggo, which is far from the center of power and reformation, the momentum has relevance because the elements, such as political parties, succeeded in providing contextualisation of the political openness. In short, the relevance of the political education program conducted by PKB can be described as follows;

First, it is an element that plays an important role in improving the quality of democracy by seeking politics without violence. In this case, it is important to describe the position of PKB in the social and political atmosphere in Probolinggo. PKB is a party that obtains a political mandate from NU so that it has the trust of Nahdliyyin community. This modality is proven with four victories in the General Elections, in 1999, 2004, 2009, and 2014, success in the elections, and played an important role in the political changes. It is indeed difficult to deny the role of parties that have received high enthusiasm from the community in the political process. PKB plays a role in guarding ongoing democracy so that it can take place without violence. Material violence can escalate widely, such as arson, fighting between two camps, murder, and so on, has rarely occurred in Probolinggo, even since reforms, it rarely occurred. In contrast to some other regions in Indonesia, the political momentum that was supposed to have the potential for violence, such as the Election, Regional Election, and the overthrow of Gus Dur in 2001 was successfully passed without violence.

Secondly, it is an element that encourages the level of participation and awareness of the people towards the political and governance processes. Compared to other regions in Indonesia, during the New Order, the people of Probolinggo were not well educated politically. The New Order's floating mass political policies separated citizens from political and government dynamics. Being a citizen means paying taxes, participating in elections without awareness and the opportunity to oversee the government, and as far as possible avoiding concern with government officials who, in their opinion, are corrupt and oppressive. Most citizens grew up in the New Order era so that politics for them was the world of the elite. Their world is day-to-day work, managing boarding schools, madrassas, and recitation, and so on. The 1998 reforms opened a new world for most Probolinggo people and raised attention to the political and governance process. Not only in the sense of increasing voter participation in elections, but in their daily lives. The establishment of PKB in 1999 and the dynamics following showed great enthusiasm from the citizens. PKB became an effective political media, which could be rationalised and easily reached by most people who were nahdliyyin. Politics and the state become an integral part of people's daily lives, the media and political activism that take place, are familiar and easily recognised. In this case, pesantren (Boarding Islamic institution) is one of the main political epicenters. Although some people worry about this because pesantren will be more preoccupied with political activism than with educational and religious activism, pesantren is a significant means of political transformation, as demonstrated by PKB in using pesantren a media for political education.

Third, PKB is a force that seeks to realise Islam rahmatan lil 'alamin. In all PKB political campaigns and activities, the discourse on Islam is always combined with two other values; Indonesian-ness (wathaniyah) and humanity (basyariyah). Islamic identity is always interpreted in the context of Indonesian and humanity so that issues such as the Jakarta Charter, Sharia Regulations, and Islamic Countries, and so on do not appear in the political discourse in Probolinggo. Interestingly, this arises amid a strong Islamic culture and Islamic boarding school. A phenomenon that can only be understood by drawing analysis into the process of changing the paradigm of the movement in NU since the 1980s. However, in contrast to NU which is more active on the level of religious social movements, PKB has brought the paradigm into the political sphere.

The fourth, PKB political education functions as an element that provides contextualisation to the climate of openness and within certain limits transform parties. Political integration in people's daily 
lives goes along with increasing public awareness of their rights as citizens. The awareness process, although sporadic, took place, for example, in PKB assistance to Binur villagers dealing with the Paiton electric steam power plant or in the case of farmer and fishermen organization.

The analytic description shows the strengths and weaknesses of PKB political education in Probolinggo as seen in the six models outlined. The analysis was also carried out by mapping the relevance, meaning, and expectations of the whole process for social and political conditions in Probolinggo. Therefore, the researcher will then place the political development of PKB as a political evolution within NU, so that it can be understood in a broader context (Amirudin, 2015).

\section{The Context of Political Transformation; from NU to PKB}

As explained earlier, the emergence of PKB in Probolinggo and national politics cannot be separated from the dynamics that have occurred at NU. PKB is a political party officially formed by PBNU (Pengurus Besar Nahdlatul Ulama - executive board of NU) in response to the reforms and political enthusiasm shown by NU's community. Although it previously was formed as a religious social organization, NU has never been separated from the tug-of-war of national political interests, even for decades after independence NU appeared as a political party. The PKB's political paradigm which included Pancasila as a party principle, its neglect of the Jakarta Charter issue, the application of Islamic Sharia in state and Islamic life as the basis of state philosophy, and its attention to secular issues such as political education would only be understood if it saw a transformation in Post-NU policy returned to khittah in 1984. However, it is difficult to understand that it would happen in the 1950s when the ideals of political Islam were still very formalistic and there was strict segregation between nationalist and religious parties. Therefore, it must be realised that NU's political journey to the emergence of PKB was not linear, complex, full of tension, and dynamic.

In principle, NU politics is based on Sunni political doctrine that emphasises harmony, as long as this harmony provides opportunities for Muslims to carry out their religious obligations (Fealy, 2003). This political norm avoids anarchy and bloodshed because anarchy can have a large negative impact. Good intentions could not be achieved by bringing up negative situations that endanger the community. If the entire ideals of goodness cannot be realised then these ideals can be realised at the level of the possible situation. In facing equally bad political choices, Sunni doctrine teaches us to choose the politics that have the least negative risk, the final result of al-dararain. With such a political basis, NU often shows political elasticity and acrobatics which its critics accuse of being opportunistic, while for its supporters it is seen as a smart political choice in a growing situation. Even if examined further, understanding tolerance and the political balance of NU must be confronted with historical realities that produce new realities, not only in the sense of internal struggles but its role as an actor who determines historical reality. Such conditions require continuous adjustment, with the understanding that NU's basic political ideas must continue to be contextualised with different political realities (Kusmayadi et al., 2016). NU's political journey for 84 years confirmed a change in its articulation and practical political objectives. During the 25 years under Dutch and Japanese colonialist rule, 20 years under Soekarno, 25 years under the Soeharto regime, and 20 years in the reform era, NU demonstrated non-monolithic political articulation. After the reform, with PKB as its most legitimate political extension, NU chose different political visions and practices. Although it must be emphasised that in its journey, PKB has its dynamics within certain limits that must be separated from NU, but all of them show the constant and changing political dynamics of NU (Ekawati, 2016).

\section{The Political Context of Post-New Order Politics}

Political education as one of the new political issues has several limitations, however, it represents a change in the paradigm of post-New Order political Islam. The emergence of Islamic parties as contestants in the 1999, 2004, 2009, and 2014 elections with the actual vote acquisition was not too disappointing and alarming for some circles. It is surprising that political Islam is believed to have disappeared in the Indonesian political atmosphere due to repressive pressure from the New Order regime, and is alarming because its emergence is expected to push back political flow in the 1950s 
(Abdullah, 1987). However, some of these parties tend to forget a fact that political Islam was built several decades before independence and in its journey was an important pillar in the political configuration in Indonesia.

The existence of political Islam in Indonesia and its vulgar return after the reformation, according to Lili Romli, can be explained by at least four factors; theological, historical, sociological, and reform factors (Romli, 2004). First, theological factors. Islam is believed by its adherents as din wa daulah (religion and state). For this reason, political matters are an inseparable part of religion and therefore need a political power built on the foundation of religion. This power is needed to realise Islamic teachings holistically. Political parties are an effort to build political power which incidentally originates from the theological viewpoint. Second, sociological factors. Islam in Indonesia is the majority religion embraced by around $87 \%$ of the 260 million population. With such a dominant number, it is natural that Muslims have ideals to color the life of the state, one of which is political power. The establishment of an Islamic party is a sociological necessity because the Muslim community, though not entirely, feels comfortable and safe channeling political aspirations to the Islamic party. Islamic parties that already have theological legitimacy are also supported by sociological facts as a real political force. Although the Islamic party has never received a vote comparable to the statistics of Muslims. This is a phenomenon that requires further explanation. Third, historical factors. Islam colors political and social life, in the form of Islamic empires which alternately reign in the archipelago and in the form of struggles to realise independence. Sarekat Islam (SI) was the first political party and the first organization to succeed in providing a blueprint for a pluralistic Indonesian entity for the birth of Nationalism. Islam is also a political force that determines the course of Indonesian history, both in the Old and New Order eras. Whereas fourth, the reform factor. The political freedom of the reform era provides an opportunity for all components of the nation to channel their political aspirations. This opportunity was used by various Islamic elements to establish political parties. These four factors are the main explanation for the rise of Islamic parties established by various elements shortly after the reformation began.

The emergence of Islamic parties after the 1998 reform was quite surprising. The power of political Islam that was thought to have been buried during the New Order came to power again in a new dynamism, which also showed that political Islam had a strong resilience during an authoritarian regime. The slogan "Islam Yes, Political Islam No" which used to be popular jargon is now countered by the enthusiasm of many parties to establish Islamic-based parties. Of the 48 parties participating in the 1999 elections, 20 of them are Islamic parties. The 20 Islamic parties have different variations, both at the level of party principles, mass basis, slogans, political expectations, and program focus. This fact suggests that Muslim political expression is fundamentally diverse. The results of research conducted by Zainal Abidin Amir on the five largest mass-based Islamic parties, namely PKB, PAN (Partai Amanat Nasional - National Mandate Party), PPP, PKS (Partai Kesejahteraan Sosial - Social Welfare Party), and PBR (Paratai Bintang Reformasi - The reform Star Party), showed a paradigmatic shift that was different from the previous generation party (Amir, 2003). Even though some of the five parties above, namely PKS (Nurussa'adah \& Sumartias, 2017), PPP, and PBR, still include the formal principle of Islam as the basis of the party but the direction of the party stands on the new paradigm.

The formulation of political Islam in the context of statehood and nationality moves evolutionarily. The struggle with the issue of religious plurality, ethnicity, modernity, authoritarian state power, demands for democratisation, and civil society are increasingly growing in the context of all these changes. New growth that occurred in the 1980s took place at three levels; the renewal of thought, bureaucratic renewal, and social transformation became the main capital for the plurality of Muslim political expression. If in the 1980s, the key actors controlling the transformation were elements of civil society and not political parties, in the reform era when political openness was possible, party roles could not be denied, or even the most decisive. The party has the infrastructure, networks, financial capabilities, representatives in Parliament, and ideology beyond other organizations (Shobron, 2013). 
Islamic parties, with a variety of issues and movements, are likely to re-enter as the main players in the national political stage. Although Islamic parties in four elections, in 1999, 2004, 2009, and 2014 failed to win a majority, the state leadership and government bureaucracy showed representations of santri (pesantren student). Dialectics between Islam and nationality has changed the direction of the Islamic movement. The fact that should change the perception of the community in Indonesia who merely see political Islam as sectarian aims. In the configuration of national politics, there is a growing need for a mechanism that provides aspirational space for political Islam. If all elements of the nation are loyal to the efforts of democratisation based on the principle of meritocracy and the mechanism is already available, political Islamic constituents do not experience frustration, let alone distrust, which drives them towards political extremism. Placing the links between political Islam and Nationalism in an oppositional relationship will only give to a counterproductive situation, on the other hand, if it is placed in a dialectical relationship will become a raison d'etre for the realisation of a democratic and just nation (Humaidi, 2018).

\section{Conclusions}

From the description above it can be concluded that the momentum of the 1998 reform became the beginning of the changes that occurred. The PKB's political experiments in the form of political education, implemented in six models as outlined in this article, indicate the transformation that took place. The experiment has serious strengths and weaknesses, but at least it becomes a political phenomenon that can be analysed in the context of political developments at the local level, marking the transformation of NU and political Islam in the political configuration in Indonesia. Will these changes be of strategic value for efforts to improve justice, democracy, and prosperity? The answer to this problem is not yet clear, nevertheless, it shows the diversity of Muslim political articulation in Indonesia, and its need to adapt to a changing context.

\section{References}

Abdullah, T. (1987). Islam dan Masyarakat; Pantulan Sejarah Indonesia. Jakarta: LP3ES.

Almond, G. A. (1997). Sosialisasi, Kebudayaan, dan Partisipasi Politik. In M. Mas'oed (Ed.), Perbandingan Sistem Politik. Yogyakarta: Gajah Mada University Press.

Amir, Z. A. (2003). Peta Islam Politik Pasca Soeharto. Jakarta: LP3ES.

Amirudin, Z. (2015). Model Communication Enggagement dalam Komunikasi Politik Calon Legislatif dalam Pemilu Umum 2014. Informasi; Kajian Ilmu Komunikasi, 45(2), 115-123.

Assyaukanie, L. (2011). Ideologi Islam dan Utopia: Tiga Model Negara Demokrasi di Indonesia. Jakarta: Freedom Institute.

Bayat, A. (2002). Post-Islamisme; Wajah Baru Islam Politik. Yogyakarta: LKiS.

Bruinessen, M. Van. (1999). NU; Tradisi, Relasi-Relasi Kuasa, dan Pencarian Wacana Baru. Yogyakarta: LKiS.

Coleman, J. S. (1965). Education and Political Development. Princeton: Princeton University Press.

Dhakidae, D. (1999). Partai-Partai Politik Indonesia; Kisah Pergerakan dan Organisasi dalam Patahan-Patahan Sejarah. In Litbang Kompas (Ed.), Partai-Partai Politik Indonesia; Ideologi, Strategi dan Program. Jakarta: Kompas.

Edy, M. L. (2006). Reformulasi Gerakan PKB. Yogyakarta: DPP PKB, Iskandarsyah Institute dan KLIK.R.

Ekawati, E. (2016). Nahdlatul Ulama (NU) sebagai Civil Society di Indonesia. Nuansa, 13(2), 233-250.

Evans, K. R. (2003). Sejarah Pemilu dan Partai Politik di Indonesia. Jakarta: Arise Consultancies.

Fealy, G. (2003). Ijtihad Politik Ulama; Sejarah NU 1952-1967. Yogyakarta: LKiS.

Feillard, A. (1999). NU Vis-à-Vis Negara. Yogyakarta: LKiS.

Ghozy, E. (2019). Pilkada dan kelembagaan Partai Politik di Daerah. Retrieved October 16, 2020, from KPU Jawa Timur website: https://kpujatim.go.id/opini/pilkada-dan-kelembagaan-partai-politik-di-daerah-oleh-erfanghozy-div-sosialisasi-kpu-kab-probolinggo/

Hasan, N. (2006). Laskar Jihad: Islam, Militancy, and the Quest for Identity in Post-New Order Indonesia. Ithaca: Cornell Southeast Asia Program Publications.

Hermawan, E. (2004). Partai Advokasi; Wacana Keberpihakan dan Gerakan. Yogyakarta: DPP PKB dan KLIK.R.

Hilmy, M. (2015). Radikalisme Agama Dan Politik Demokrasi Di Indonesia Pasca-Orde Baru. MIQOT: Jurnal Ilmu-Ilmu Keislaman, 39(2), 407-425. https://doi.org/10.30821/miqot.v39i2.33 
Humaidi, Z. (2018). Dialektika Islam Politik dan Nasionalisme: Analisis Restrospektif. Proceedings of Annual Conference for Muslim Scholars, 889-903. Surabaya: Kopertais IV Surabaya.

Keddie, N. (1986). The Islamist Movement in Tunisia. Maghreb Review, 1(1), 26-39.

Kersten, C. (2018). Berebut Wacana. Bandung: Mizan.

Kusmayadi, E., Agung, S., \& Andrias, M. A. (2016). Model Kepemimpinan Politik Kiai: Studi Peran Kiai Dalam Pergeseran Perilaku Politik Massa NU PKB dan PPP. Politika: Jurnal Ilmu Politik, 7(2), 21-33.

Lay, C. (2006). Involusi Politik; Esei-Esei Transisi Indonesia. Yogyakarta: PLOD.

Liddle, R. W. (1972). The 1977 Election and New Order Legitimacy. In L. Suryadinata (Ed.), Southeast Asia Affairs 1978 (pp. 3-17). Singapore: ISEAS.

Litbang Kompas. (2004). Partai-Partai Politik Indonesia; Ideologi dan Program 2004-2009. Jakarta: Kompas.

Nurussa'adah, E., \& Sumartias, S. (2017). Komunikasi Politik Partai Keadilan Sejahtera (PKS) dalam Keterbukaan Ideologi. Jurnal Kajian Komunikasi, 5(1), 43-52.

Romli, L. (2004). Partai Islam dan Pemilih Islam di Indonesia. Jurnal Penelitian Politik, 1(1), $29-48$.

Salim HS, H., \& Fauzan, U. (1999). Tujuh Mesin Pendulang Suara. Yogyakarta: LKiS.

Shobron, S. (2013). Prospek Partai Islam Ideologis di Indonesia. PROFETIKA; Jurnal Studi Islam, 14(1), 9-24.

Tim DPP PKB. (1998). Menyambut Deklarasi Partai Kebangkitan Bangsa. Jakarta: DPP PKB.

Tim DPP PKB. (2002a). Dokumen Muktamar Luar Biasa PKB. Yogyakarta: DPP PKB.

Tim DPP PKB. (2002b). Hasil-Hasil Mukernas, Munas Alim Ulama', Muspim dan Rakornas Dewan Syura. Jakarta: DPP PKB.

Voll, J. O. (1997). Politik Islam; Kelangsungan dan Perubahan di Dunia Modern. Yogyakarta: Titian Ilahi Press.

Wahyuddin, G. (2016). Relasi Islam dan Politik di Indonesia. Jurnal Adabiyah, 16(1), 70-82.

Weiner, M., \& La Palombara, J. (1981). Pengaruh Partai terhadap Perkembangan Politik. In M. Budiarjo (Ed.), Partisipasi dan Partai Politik. Jakarta: Gramedia.

(C) 2020 by the authors. Submitted for possible open access publication under the terms and conditions of the Creative Commons Attribution (CC BY SA) license (https://creativecommons.org/licenses/by-sa/3.0/). 